\title{
Students' Perspective on the Emotional Intelligence of Teachers on Student Engagement
}

\author{
I. Welmilla ${ }^{1}$ \\ ${ }^{1}$ Senior Lecturer, Department of Human Resource Management, Faculty of Commerce and Management Studies, \\ University of Kelaniya, Sri Lanka \\ Correspondence: Dr. (Mrs) I. Welmilla, Senior Lecturer, Department of Human Resource Management, Faculty \\ of Commerce and Management Studies, University of Kelaniya, Sri Lanka.
}

\author{
Received: January 2, $2020 \quad$ Accepted: March 11, $2020 \quad$ Online Published: March 20, 2020 \\ doi:10.5539/ibr.v13n4p30 URL: https://doi.org/10.5539/ibr.v13n4p30
}

\begin{abstract}
Student Engagement has emerged as a central theme in the context of Higher Education in recent years. Thus, there is great consent towards it. Due to several factors, undergraduates are diverted and disengaged consequently, especially the state universities of Sri Lanka currently experiencing this issue. Even there are many factors impact student engagement. This study explored the significance of teachers with their emotional intelligence competencies for getting student engagement. University students prefer to take student-centered teaching where it is possible if only teachers are ready and capable to take account of students' interests, needs, and perspectives on adaptation with their teaching approach. Having understood the phenomenon above, the current study designed to investigate the impact of the emotional intelligence of teachers in higher education on student engagement based on students' perspectives. This is an explanatory study that the data collected from the sample of 1455 undergraduates selected from the state universities in Sri Lanka on which stratified random sampling method was adopted. Finding reveals that students are engaged but not actively and as per the students' point of view lecturers are just good rather excellent enough on emotional intelligence competencies. However, there is a strong positive relationship as well as have a significant positive impact of emotionally intelligent teachers of higher education on student engagement. Ultimately it is concluded that higher education teachers require to expand the substantial amount of skill on emotional intelligence. Further, then active student engagement can be ensured.
\end{abstract}

Keywords: emotional intelligence, higher education, teachers, Sri Lanka, student engagement

\section{Introduction}

Professionals of the nation grow with the guidance of teachers; indeed, they are the living legends for the individual as well as the national development as a whole; consequently, the country's development depends upon individuals' development. According to the educational system of Sri Lanka, from six years, up to eighteen students spend most of the time by Schooling (Primary and Secondary education). Once eligible to attend universities another three or four more years (with relevant to the degrees) spending with, and it will be carried in the form of Masters, $\mathrm{PhDs}$, and so on.

It indicates that teaching professionals are life driven factors for every human being, so teachers are the ever forgotten relationship that everyone comes across in their life. Hence, all have great memories of teachers. According to Hargreaves (1998), teaching is a form of emotional labor, so teaching professionals require emotional intelligence to an extent. Concerning many authors' concerns, emotional labor is a medium used to generate commercial value. In contrast, teachers with emotional competency have been considered caring, motivating, communicating, and understanding the real need of students (components of emotional intelligence). Moreover, guide students to become successful in their academics as well as their personal life under which this study gives prime attention towards the emotional intelligence competencies of teaching professionals of the higher education sector, especially the state universities in Sri Lanka.

Most of the students prefer to adopt their teachers as role models (Singh, 2015) in their life it is not only merely because of technical and other competencies. There is something unique feature of them adopted by the teachers; it might be the teaching pattern that correlates with students' expectations and consents. Lecturers are competent enough on subject areas, how handling emotion at work also matters in this era since the generation is come up 
with different needs and wants. Nowadays, the younger generation is expecting care and attention from their teachers because teaching is considered a front line profession, managing emotion supposed to be a paramount factor for them, and it would be beneficial for both teachers and students.

Since school days, students depend upon many factors such as parents, colleagues, relatives, society, and teachers. However, they become full of freedom when they are at higher education (Nassudin, 2012) because of maturity and the sense of feeling everything known and managed by alone themselves. Getting university entrance is a great achievement because every student who sat for the advance level exam unable to get the opportunity due to the high competition and standard of the education system in Sri Lanka. This transition demands following adaptation challenges such as culture, attitude, behavior, psychological factor, social and ecological context, and perception of the university environment and so on (Nassudin, 2012). These challenges either negatively or positively impact on students' engagement towards academics.

There is a dominant trend of undergraduate disengagement, and the amount of time students spends studying and participating in on-campus activities has decreased in this contemporary world (Phommasa, 2016). Nina (2015) at Opole University revealed that students could be disengaged or even drop out of the studies due to had an unfair treatment or negative attitude from their lecturers. So it does not indicate that lecturers lack competencies. It partially connected with the state of emotional well beings. Currently, emotional intelligence is of great importance for teaching professionals of higher education. It does not only generate harm to the students. It can be affected by parents' expectations. Government budgeting a large amount of money on higher education becoming in vain, society loss of educating generation country lacking to produce people who brought up the country to the next stage (Developed country). Hence teachers preferably with technical skills regarding subject areas needed to improvise psychological factors to get students engagement towards academics.

However, there is a shortage of studies had been undertaken so far separately to identify the factors which influencing student engagement and the significance of emotional intelligence competencies for teachers of higher education to perform their job well. According to Kahu (2013), teaching has a significant impact on student engagement in higher education, whereas further researches have not undertaken to shed the light of significance on the emotional intelligence competencies of the lecturer for getting student engagement. If lecturers wanted to take a student-centered teaching approach as per the willingness of the current generation they are supposed to develop the emotional intelligence competencies, it tremendously assures the student engagement too. Signifying lecturers' emotional intelligence competencies on student engagement is still an unexplored area. This is the gap that the current study had explored. Hence, the present study examines how teachers' emotional intelligence affect student engagement in state universities in Sri Lanka. In addition to that, the study was attempted to analyze teachers' emotional intelligence competencies based on the students' perspective because there are two ideologies stand to define what emotional Intelligence is, understand one's self and others and their feeling. (Goleman, 2006).

Thus, the study mainly focuses on the ideology that understanding students feeling, wants, and interests. The teachers in the higher education sector understand students' needs well. Students realized by the teachers that the student can reveal the reality whether he or she is cared for and recognized by then it is generating real outcome and use full for lecturers to adopt an active teaching pattern that met the students' expectations too. There are some studies (Bashir, Bajwa, \& Rana, 2014; Madelina, 2007) in the emotional intelligence area. But the response about understanding oneself and others is given by one individual him or herself; however, whether he or she follows others correctly can reveal better than other parties who are supposed to understand that is where the background used in this study. Ultimately students were given a chance to measure whether their lecturers competent enough at managing their emotion effectively in terms of social awareness and relationship management and turn whether its impact on student engagement also had been studied.

\section{Literature Review}

\subsection{Emotional Intelligence}

Emotional intelligence is a phenomenon drawn from the psychological arena, and it is rooted in much earliest social and psychological theories. After the publication of the best-selling book named "Why, It Can Matter More than IQ?" by behavioral researcher Goleman (1998), the emotional intelligence concept became popular as well as acknowledged to the broader population. Emotional intelligence is about understanding one's feelings, sympathy for the opinions of others, and the dictate of sense in a way that improves living (Goleman, 2006).

Goleman has introduced the competency model for emotional intelligence (as cited in Adel Alferaih, 2017). It involves two main components, namely personal competence and social competence. First one, personal competence mentions that an individual should understand his or her self well, which contains self -awareness, 
and self- management. The next emotional intelligence of social competence is expanding social awareness and relationship management. The current study focuses explicitly on social competence, which stands for how well an individual manages relationships, including others. Further, it can categorize into two dimensions, which are social competence of social awareness and social competence of relationship management.

Social awareness includes increasing their awareness to keep the emotions of individuals around them, and it covers an individual's ability to read an emotional environment, so to be socially aware, an individual need to demonstrate the following competencies, such as sympathy, organizational awareness, and facility direction. Relationship management is the other dimension that refers to personal use awareness of individual and others' emotions to create a secure, effective, and long-term relationship. Goleman (2006) identifies several competencies such as impact, leadership, evolving others, communication, change catalyst, conflict management, and generate the bond.

\subsection{Models on Emotional Intelligence}

Emotional intelligence can be used to define what emotional intelligence is, and it enriches to draw a clear picture of it as well. Despite there were many scholars who worked on the emotional intelligence concept for first and foremost the term of emotional intelligence. Mayer and Salovey (1990) published their landmark article named emotional intelligence in a journal. Hereafter onwards, people got to know the concept of emotional intelligence to some extent. Based on that, there were various definitions, theories, and models that are emerging. According to Mayer \& Salvoey (1990), emotional intelligence refers that the ability to control the own and other's feelings and emotions that are influencing the discriminate against each other and using this information to guide one's thinking and action lead to emotional feelings. It consists of the following four components, such as the ability to accurately perceive information, the ability to use emotions to assist thought, the ability to understand emotion, and the ability to manage or regulate emotion. These components must be measured through cognitive ability-based IQ tests. The problem-solving items are designed to test a person's abilities, and it simply indicates that emotional intelligence is limited to the boundary of cognitive ability or mental ability of an individual.

Psychologist Konstantin Vasily Petrides develops a trait model of emotional intelligence. It focuses on emotions of self-perception, on the other hand, this model believes that an individual who well at recognizes and utilizes his or her feelings become capable of understanding while manipulating emotions with whom they are networked. Simply it refers capable of predicting the emotional abilities of others based on his or her perspective. This is the most recent model developed based on personality characteristics (Petrides, Pita \& Kokkinaki, 2007). Emotional intelligence is defined as "a constellation of behavioral dispositions and self-perceptions concerning one's ability to recognize, process and utilize emotion-laden information" (Petrides \& Furnham, 2003, pp41). This model emphasizes that an individual who is highly focusing on emotions and personalities of him or her rather others.

The mixed model is another universal fame model introduced by Goleman (1998). The mixed model consists of five components that reflect emotional competencies, and those competencies cover neither inherent characteristics nor personality traits of an individual at most significant place has been given a set of emotional skills and competencies of an individual, and it leads leadership performance. The first component of competence is self- awareness that revels the ability to know one's emotions, strengths, weaknesses, drives, values, and goals and identify their impact on others while still using gut feelings to steer decision. Second, selfregulation that involves controlling or redirecting one's unruly emotions and desires and adapting to varying situations. The third component is social skills that means managing relationships to move people in the desires and adapting to varying conditions. Next, empathy concerns other people's feelings, particularly when making decisions. Finally, the motivation that is driven to achieve for the sake of attainment (Goleman, 1998). However, in 2001 it is renewed in the name of the Competency model by consisting following constructs by Goleman. Specifically, it is designed to apply to workplaces, and it contains twenty competencies under four dimensions. It is used to differentiate an individual from another in a work station. Self-awareness; the ability to understand the feelings and accurate self-assessment, self-management; the ability to handle internal states, impulses, and resources, social awareness; the ability to read people and groups, and relationship management; the ability to encourage desirable responses in others (Goleman, 2001). The research is undertaken based on these two models. Ultimately these models mentioned that leading a successful life is determined by the development of emotional intelligence while focusing on characteristics by the nature of an individual that is inherent to them too. Those four components can be divided into two dimensions, namely personal competence and social competencies. Personal competence refers to an individual who should understand themselves well, which is one half of developing your emotional intelligence and which encompasses with self-awareness and self-management. 
Social competence has mentioned the ability to recognize those around you. Nevertheless, both competences should equally support to develop emotional intelligence.

\subsection{Emotional Intelligence and Teaching}

There are series of research study had been undertaken with the interest of teachers' emotions by specially underpinning university lectures (Constanti \& Gibbs, 2004; Ogbonna \& Harris, 2004; Zhang \& Zhu, 2008). Teaching is primarily deemed as a rational, rhetorical, and relational communication process in which teachers strategically use messages and relational cues to influence students and their behavior (Mottet \& Beebe, 2006). Ahmed (2015) mentioned that teachers are the paramount factors in an educational hub, and emotional intelligence is having a direct impact on teachers' performance since it is a dimension of social science. According to Hargreaves (1998), emotions are at the heart of teaching and teachers' lives as well. Undertaken series of research on emotional intelligence for teaching professionals is witnessed that prime attention supposed to be paid towards teaching emotions.

Ultimately all the studies revealing teachers should ensure students are effectively attended to more on studies, motivated, and active conduct of the classroom is taken in place as well. According to Embry (2002), alone being on book knowledge might not be a true indication of a quality teacher; it should focusing beyond subject matters as well. Good teaching is in line with positive emotions; being certified teachers does not adequate; it must belong by being emotional, building effective rapport with students, creativity, challenge, and joy, so teaching involves significant emotional understanding (Hargreaves, 1998b). Thus it implies that teachers should focus on other excellence rather than book knowledge in terms of emotional skills and competency to get student engagement. Trigwell (2012) stated student-focused teaching would be taken place once teachers are associated with positive emotions and vice versa.

Singh (2015), in his book, mentioned high emotional intelligence skill is required for teachers in terms of rapport, harmony, and comfort while dealing with groups. If the teachers have a passion for their profession, they will be dedicated, keen, and rationally, emotionally, and morally energetic in their work with students, colleagues, and others around them in their work station. Indeed teaching is an emotional process in which teachers can manage, monitor, and regulate their emotions to achieve teaching effectiveness and to create a positive learning environment.

Schools are social processes besides learning is an intrinsically social process; thus, teachers should well be equipped with the knowledge and practice of emotional skills. In turn, it induces students to become engaged in leanings and which contributes to their fullest potentials as well (Ergur, 2009). The holistic development of the students is the ultimate goal of education. There should be an effective communication process between teachers and students to influence students to be engaged. Higher education is demanding excellent communication between teachers and students; it seemly either formal or informal settings; in turn, a positive correlation with motivation would be appeared (Lowman, 1984).

Similarly, teaching should be paid attention to managing emotions to cultivate a climate that generates positive learning (Mottet \& Beebe, 2006). The argument brought up by Brackett and Katulak (2006) emotionally intelligent teachers can able to nurture the safest, satisfied, cared, and productive learning atmosphere. A positive classroom outcome can also be associated with teachers who are emotionally competent in influencing students (Krementizer \& Miller, 2008). Where Teaching is considered a front line profession, managing emotion supposed to be a paramount factor for them, and it would be beneficial for both teachers and students (Winograd, 2005). The emotionally competent to manage or use their emotions well in a workplace, it depends on what emotional state is expected from their job or profession and how their organizational structures demand human interactions in ways that help or impede emotional expression and understanding (Hargreaves, 1998b).

Jennings and Greenbeing (2009) suggested that an emotional bond can be cultivated by being socially and emotionally competent enough. Those who emotionally competent can develop lessons to bring out students' abilities and strengths; moreover, students take their teachers as role models too. Richardson and Shupe (2003) found that teachers who thorough at self-awareness facilitate understanding how students can affect teachers' emotional processes. To become emotionally intelligent, teachers should be competent at self-awareness and social-awareness.

On the one hand, teachers are well known about their strengths and weaknesses and how their emotional expression affects interaction with others another side; they capable of recognizing others' emotions. This directs us to have a mutual rapport with people around you (Greenberg et al., 2003). Thus it can be built up a sensible connection with students. Ultimately Emotionally Intelligent teachers contribute towards students learning performance (Cohen, 2006). Once become a teaching professional, the emotional intelligence training preparation program would enrich emotional competence, and it results in a long term positive effect on 
education (Chechi, 2012; Edannur, 2010; Mendes, 2003). People who good at emotional intelligence predict others' sentiments well and make them excited and motivated (Cooper, 2004).

Teacher's empathy stands for the ability to perceive students' feelings. In other words, attention paid towards students' perspectives and concerns this where a process of understanding student's feelings in place of students (Tettegah \& Anderson, 2007). According to Ergu (2009), teachers with emotionally intelligent are the initiatives for an empathic learning environment for their students, and then they become a moral model to students. In the meantime, students are treated as unique individuals and valued in terms of their feelings. According to Deniz (2010), teaching is a process involving emotional practices like many other activities involving human interactions. Teachers monitor their students all the time in which they would check their appearances of engagement, or responsiveness. When teachers' emotional scanning goes wrong, what they experience is an emotional misunderstanding, and the perception of students feeling becomes completely wrong (Hargreaves, 1998). Teachers misunderstanding students' needs tend to lead misjudgment on students' leanings. To be emotionally engaged or understand students' needs, strong bonding between teachers and students might endeavor to read about each other over a while (Hargreaves, 1998).

The classroom of a student is a next home environment for them, and teachers are the dominant influence factor on student achievement as well (Hammond, 1999). According to Rust (2014), emotionally intelligent teachers enable to understand of the state of students' needs and having strengthened control over the classroom; in turn, it will have an impact on student engagement in their academics. Emotional intelligence has a positive relationship with teachers' classroom management, and emotional intelligence can be a good predictor of functional classroom management styles (Hamdan, 2007). Futhermore Hamdan (2007) stated that classroom management minimizes tensions inside the class, moderates students' behavior, listens to students' ideas and suggestions, encourages students to do the best of them, and pay attention to their needs and concerns.

Effective classroom management builds positive rapport between teachers and students; additionally, the teaching pattern would cater to students' requirements. Inaugurating a positive classroom climate can generate effective teaching and learning; it can be termed as classroom management. Ultimately classroom management is teachers' efforts to led the students' achievement (Good \& Brophy, 2006; Ritter \& Hancock,2007). Although emotional intelligence positively correlates with classroom management, poor classroom management due to lack of emotional intelligence, competencies students turn demotivated $(\mathrm{Hu}, 2011)$. Hence it would negatively impact student engagement.

Although teaching is a privileging profession, it is lead them to burn out, which means stressful occasions unless teachers capable of managing emotions effectively because educators are live in the time of rapid change and increased demands. That's what they require a substantial amount of skill on emotional intelligence because it will negatively impact their career as well as students' engagement. A teacher is playing a major role in building ethical values on students in terms of self-discipline and empathy. The quality of education should be ensured by emotionally intelligent teachers who, well at emotional skills, help students to become motivated, increased performance, collaborate with the team, and effective use of resources and time. Finally, it indicates that competent at emotional intelligence skills by teachers is an influencing factor on student engagement. According to Singh (2015), the enhancement of emotional intelligence should require in the field of higher education. Moreover, the teachers who demonstrate a higher level of emotional intelligence are empathic and preoccupied with the students' emotional life. Such teachers adopted a friendly and warm approach towards the students by motivating, encouraging, and treating them without any bias (Singh,2015). The teacher is a major influential factor in students' engagement to a great extent. In such a case, teachers who exhibit a higher level of emotional intelligence determine the students' overall school performance as researchers indicate (Brackett \& Katulak, 2007; Pekrun et al., 2002; Petrides et al., 2007), an emotionally encouraging class environment positively influences students' academic achievement. Emotional intelligence is not a born skill; the involvement of an individual can develop it.

Based on that where an individual who competent at managing emotions well through developing emotional intelligence competencies, which are stated above, can deliver high performance whereby teachers can ensure that students to be engaged in their learning through developing social skills based on Goleman. In this study, university students are surveyed to explore whether their lectures are understood their state of feelings and are it a major factor for them to be committed to academics activities. In this contemporary world, teaching professionals are demanded various skills; one of such fundamental competence is emotional intelligence. Teachers are the paramount factors in an educational hub, and emotional intelligence competencies, having a direct impact on teachers' performance since it is a dimension of social science (Ahmed, 2015). According to Hargreaves (1998), feelings are at the heart of learning and teaching, and the education process is considered a 
front line profession; managing emotions supposed to be a paramount factor for them, and it would be beneficial for both teachers and students (Winograd, 2005). According to Embry (2002), alone being on book knowledge might not be an accurate indication of a quality teacher. It should focus beyond subject matters, as well. Trigwell (2012) also stated that student-focused teaching would be taken place once teachers are associated with positive emotions and vice versa. Moreover, Singh (2015), in his book, mentioned higher education teachers should demonstrate a high level of emotional intelligence skills.

\subsection{Student Engagement}

In education, student engagement refers to the amount of care, curiosity, awareness, positivity, and desire that the learners show when they are knowledge or being skilled, which spreads to the level of inspiration they have to learn and develop in their education. Students with a greater sense of confidence, hopefulness, efficacy, and flexibility will exhibit a greater level of engagement (Kyle, Brett, Lathan, Noel \& Palmer, 2016). Jennifer, Phyllis, and Alison (2004) developed three dimensions that can be used to express students' engagement. First, the behavioral engagement that stands students is complying with positively. Secondly, an emotional involvement that stands students would experience emotional responses such as attention, enjoyment, or a sense of belonging. Finally, the cognitive engagement that students would be spent in their learning would seek to go beyond the necessities and would pleasure at challenges.

Ultimately student engagement is positive correlates with greater graduation rates, higher grade point averages (GPAs), and a higher level of educational satisfaction (Astin \& Sax, 1998; Kuh et al., 2005). Academic performance can be ensured by active engagement. Higher educational institutions treat their teachers as a target for improving student engagement (Kahu, 2013). Classroom of a student is a next home environment, and teachers are the dominant influence factor on student achievement, and it is influenced by emotional aspects of the teaching process as well (Brackett \& Katulak, 2007; Edannur, 2010; Nicolini, 2010; Kremenitzer, 2005).

According to Markwell (2007), even though it is small or large on the scale of class, lectures should include effective initiative interaction among students and use feedback to make students are engaged. Hence teachers are taking a significant part in the students' university life, so teaching professionals should be paid attention to managing emotions to cultivate a climate that generates positive learning (Mottet \& Beebe, 2006). A statement raised by Brackett and Katulak (2007) was that emotionally intelligent teachers could able to nurture the safest, satisfied, cared, and productive learning atmosphere.

Finally, emotionally intelligent teachers contribute to students learning performance (Cohen, 2006). According to Ruster (2014), emotionally intelligent teachers enable to understand the state of students' need and having control over the classroom, and that will have an impact on student engagement on academics. Teachers who exhibit a greater level of emotional intelligence ensure students are effectively attended to more on studies, motivated, and active conduct of the classroom is taken in place as well (Ruster, 2014).

People who show a better level of emotional intelligence, successful at their job, and they are most welcome by corporations as well. A parallel relationship may occur in the field of higher education between teachers and students who exhibit improved levels of emotional intelligence. They are considered as emotional labor as front line professionals and their students' academic achievement (Rust, 2014). Further, he mentioned that teachers' effectiveness does not only depend upon core subjects and years of experience; indeed, the emotional dispositions of teachers encourage the student to be engaged more in studies. According to Othman et al. (2008), as a tool, teachers' performance can be measured by the academic achievement of their students. Thus they are playing a prominent role in getting student engagement on which the importance of emotional intelligence could be placed.

According to the literature mentioned, the following conceptual framework (figure 1) was developed for the study.

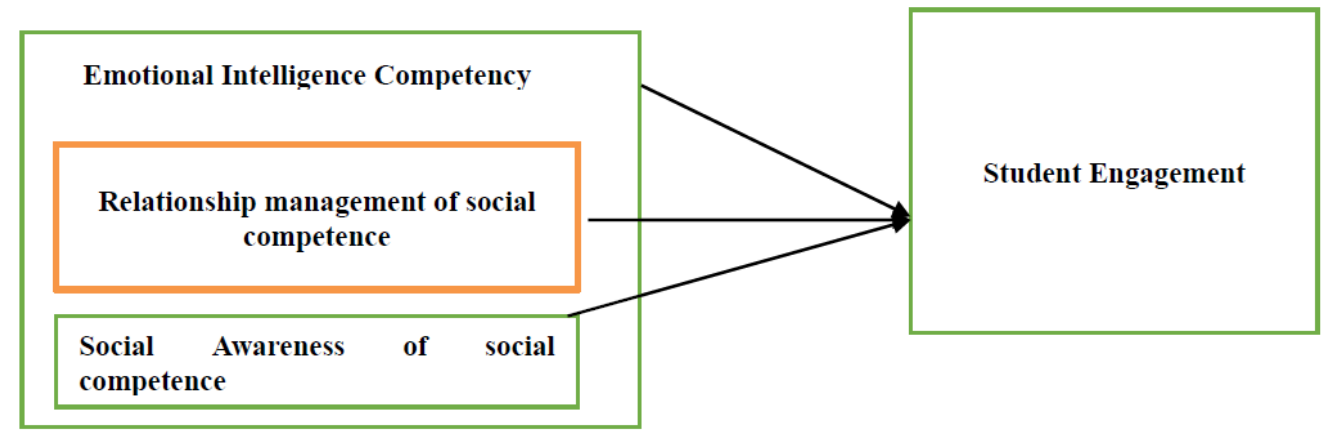

Figure 1. Conceptual Framework, Source: Author construct, 2019 
The researcher advanced the following hypotheses according to the reviewed literature.

$\mathrm{H1}$ : There is a significant relationship between the emotional intelligence of teachers and student engagement in the higher education sector.

$\mathrm{H} 1_{\mathrm{A}}$ : There is a significant relationship between social awareness of teachers and student engagement in the higher education sector.

$\mathrm{H} 1_{\mathrm{B}}$ : There is a significant relationship between the relationship management of teachers and student engagement in the higher education sector.

$\mathrm{H} 2$ : There is an Impact of the emotional intelligence of teachers in higher education on student engagement.

\section{Research Methodology}

The hypotheses have been developed in order to fulfill the main objective of identifying how emotionally intelligent teachers of higher education impacts on student engagement. Moreover, it is intended to satisfy the specific objectives such as; to determine the relationship between the emotional intelligence of teachers and student engagement in the higher education sector: to identify the relationship between social awareness of teachers and student engagement in the higher education sector and to identify the relationship between the relationship management of teachers and student engagement in the higher education sector. Here the researcher has investigated the effect of teachers' emotional intelligence on student engagement; thus, variables are neither manipulated nor controlled for study. Hence, the study was conducted in a non-contrived setting. As the data for this study were collected at a single point in time (Sekaran, 2006), the study was cross-sectional in the time horizon.

The study focused on the impact of teachers' emotional intelligence on students' engagement in Sri Lankan state universities. Therefore, to full fill the study objectives, the quantitative research approach is used to verify the advance hypotheses. The respondents were all students from state universities of Sri Lanka. The population element has known, the researchers used a stratified random sampling technique. However, this study chose a disproportionate type of stratified random sampling method. Because through the disproportionate stratified random sampling technique, the researchers can use the equal number of participants from each gender that leads to achieving realistic findings. The perceptions of 1455 students learning at Sri Lankan state universities was planned to gather a through a self- administrated questionnaire.

A pilot study was conducted to test questionnaires to test the validity of the items. To test the reliability, Cronbach Alpha was tested. The selected primary data was coded and analyze be suing SPSS Version 22. The purpose of testing the hypotheses, correlation, and regression analysis tests were performed.

\section{Analysis}

\subsection{Reliability of the Instrument}

The external reliability of the instruments used to collect data was examined by using the Test-retest method. As shown in table 2, the coefficients of the Test-retest figure of the instruments indicate that each instrument has high external reliability.

Table 2. Results of test-retest

\begin{tabular}{|lc|}
\hline Instrument & Test-Retest \\
\hline Emotional Intelligence & 0.877 \\
\hline Student Engagement & 0.762 \\
\hline
\end{tabular}

Source: Data analysis results, 2019

The inter-item consistency reliability was examined with Cronbach's Alpha value. The results of Cronbach's Alpha test are given in table 3, which suggested that the internal reliability of each instrument is a satisfactory level. 
Table 3. Results from Cronbach's alpha coefficient

\begin{tabular}{|lc|}
\hline Instrument & Cronbach's Alpha \\
\hline Emotional Intelligence & 0.921 \\
\hline Student Engagement & 0.801 \\
\hline
\end{tabular}

Source: Data analysis results, 2019

\subsection{Validity of the Instrument}

The content validity of the instrument was ensured by the operationalization of the constructs on literature, indirectly by the high internal consistency reliability of the instruments, as indicated by Alpha.

The construct validity of the variables of the study was ensured by the fact that the correlation and regression analysis support the hypotheses formulated linking the relationship between independent variables and the dependent variable. Table 03 represents the descriptive statistics of the independent and dependent variables.

Table 4. Univariate analysis of the variables

\begin{tabular}{|lcccc|}
\hline Variables & Mean & Standard Deviation & Skewness & Kurtosis \\
\hline Student Engagement & 3.4237 & 0.61648 & -0.64 & -0.401 \\
\hline Emotional Intelligence & 3.3440 & 0.61445 & 0.022 & -0.051 \\
\hline Social Awareness of social competence & 3.3416 & 0.67521 & 0.033 & -0.15 \\
\hline Relationship management of social competence & 3.3449 & 0.61846 & -0.041 & -0.041 \\
\hline
\end{tabular}

Source: data analysis results, 2019

The mean value used to analyze the central tendency of developed variables individually, especially the mean value, is used to analyze the students' exact opinion about their academic engagement and lecturers' emotional intelligence competency. To make sure their error-free questionnaire was adopted for the study, it is measured where it lies at the accepted threshold level of standard deviation. Based on the value of skewness and kurtosis, the study reveals that the data is normally distributed. The study is a cross-sectional study; data was gathered over a period of weeks. Further, correlation analysis and regression analysis are done to test the advanced hypotheses and to draw conclusions.

\subsection{Bivariate Analysis}

The bivariate analysis includes the correlation analysis and the simple regression analysis, which were used to investigate any relationship between students' engagement and emotional intelligence of teachers. Using the Pearson product Movement Correlation with the two-tailed test of significance, the correlation analysis was made to investigate any relationship between students' engagement and emotional intelligence of teachers. The results of the Pearson's correlation shown in table 05, there is a significant positive correlation between emotional intelligence of teachers and student engagement in the higher education sector.

Table 5. Correlation analysis between emotional intelligence and student engagement

\begin{tabular}{lcc}
\hline Measures & $\begin{array}{l}\text { Pearson } \\
\text { Values }\end{array}$ & $\begin{array}{c}\text { Correlation } \\
\text { Significance } \\
\text { Value }\end{array}$ \\
\hline $\begin{array}{l}\text { Emotional Intelligence of Teachers (EI) in Higher Education and Student } \\
\text { Engagement }\end{array}$ & 0.703 & 0.000 \\
$\begin{array}{l}\text { Teachers' Social Awareness (SA) in Higher Education and Student } \\
\text { Engagement }\end{array}$ & 0.640 & 0.000 \\
$\begin{array}{l}\text { Teachers' Relationship Management (RM) in Higher Education and Student } \\
\text { Engagement }\end{array}$ & 0.698 & 0.000 \\
\hline
\end{tabular}

Source: data analysis results, 2019 
The Pearson Correlation is 0.703 , suggesting that there is a strong positive relationship between the emotional intelligence of teachers in higher education and student engagement. It was attained by the significance value of 0.000 at $99 \%$ of the confidential level. Hence the founded correlation coefficient is statistically significant. Thus it is obvious to accept the Hypothesis (H1) is that there is a significant relationship between EI of teachers in higher education and student engagement.

Further, it is separately analyzed the correlation coefficient of the subdivision of emotional intelligence underlined on the conceptual framework. It is also revealed there is a moderate positive relationship between each construct on student engagement at the 0.000 of the significance level. It is about 0.640 between social awareness of teachers in higher education and student engagement at the same time, and it is about 0.698 between relationship management and student engagement. Accordingly, it is obvious to accept the sub Hypotheses $\left(\mathrm{H} 1_{\mathrm{A}}\right.$ and $\left.\mathrm{H} 1_{\mathrm{B}}\right)$ developed under the main Hypothesis $(\mathrm{H} 1)$.

The researcher has selected a simple regression analysis to determine the impact of the emotional intelligence of teachers on student engagement. According to the results of the simple regression analysis shown in Table 06, there is a significant positive impact of the emotional intelligence of teachers on students' engagement of the respondents.

Table 6. Simple regression analysis of emotional intelligence of teachers on student engagement

\begin{tabular}{|c|c|}
\hline Measures & Value \\
\hline $\mathrm{R}$ & $0.703^{\mathrm{a}}$ \\
\hline R Square & 0.494 \\
\hline Adjusted R Square & 0.492 \\
\hline Frequency & 246.884 \\
\hline Significance & 0.000 \\
\hline \multirow[t]{2}{*}{ Collinearity Statistics } & 1.000 \\
\hline & 1.000 \\
\hline Unstandardized B - Constant & 1.066 \\
\hline Unstandardized B( the slope) & 0.705 \\
\hline
\end{tabular}

Source: data analysis results, 2019

It illustrates that $49 \%$ of the variance of student engagement on academic activity is explained by the emotional intelligence of teachers in higher education. Accordingly, $49 \%$ of student engagement in academics is influenced by emotionally intelligent lecturers. The significance of the study is about 0.000 , which implies that there is a significant positive impact of emotionally intelligent teachers in higher education on student engagement. Finally, these findings enrich to accept the Hypothesis (H2), is that there is a significant positive impact of emotionally intelligent teachers in higher education on student engagement.

\section{Discussion of Findings and Implications}

Ultimately the findings reveal that students are engaged in academic activities up to an extent but do not commit themselves to participate actively because the mean value for student engagement is around 3.4237. It is an average point, so students still have a particular problem to engage their academic activities actively. As per the undergraduates' perspective, lecturers are rated on intelligent, emotional competencies as good but not excellent enough because here also the mean value of emotional intelligence competencies is around 3.344.

However, $49 \%$ of student engagement is explained by the emotional intelligence competencies of teachers in terms of interest in taking students' consent and trying to understand their perspectives. Teachers are personally available to serve and capable of persuading students' expectations, being a role model, developing graduate to cope up, being an excellent communicator, eradicating clashes with students, and build an affective bond between lecturers and undergraduates. There is a great impact of teachers' emotional intelligence competencies, especially social awareness, and relationship management on student engagement. 
A model developed by Kahu (2013) on student engagement in higher education reveals that there are many factors influencing student engagement in which teaching also plays a major role. Most of the study reveals that being qualified teachers is not only a good indication for teaching it required beyond the subject excellence, one of which is emotional intelligence (Embry, 2002; Rust, 2004). According to Singh (2015), the enhancement of emotional intelligence should require in the field of teaching professionals of higher education.

A study proposed that increased students' commitment or performance is related to maintaining a higher level of emotional intelligence of teachers (Rust, 2014). Similarly, student achievement is influenced by the emotional aspects of the teaching process (Edannur, 2010; Nicolini, 2010; Kremenitzer, 2005). Thus teaching professionals should keen on managing emotions to cultivate a climate that generates positive learning (Mottet \& Beebe, 2006). According to Rust (2014), emotionally intelligent teachers enable to understand the state of students' need. Also, having strengthened control over the classroom in turn, it will have an impact on student engagement in academics. Furthermore, an investigation by Hadi and Mohammad (2016) reveals that there is a statistically significant relationship between emotional intelligence and classroom management for a positive outcome. Hence reviews that were underpinned by the earlier researchers on emotional intelligence and student engagement witnessed that there are a positive relationship and significant impact in between advanced variables.

Especially caring relationships between teachers and students are considered as personal angle, not as a job requirement (Oplatka, 2007). However, other service organizations considered it is a requirement for emotional labor. Caring on students covers all motivational surrounding (Giardini \& Frese, 2006) and which binds an effective relationship between students and teaching professionals, and it derives a positive commitment towards academics as well.

However, teaching is a form of emotional labor (Hargreaves,1998). Therefore, the study denotes even several factors are influencing students' engagement teachers' emotional intelligence competencies on teaching approach have a significant impact. Thus, if it is considered as a job requirement for lecturers can grant an even more prominent place for developing these competencies.

According to Goleman (2006), emotional intelligence is not a borne skill, and it can be improved accordingly. Current study direct teachers to develop a substantial amount of emotional intelligence skills as long as conducting a training program in line with this content assist them to improve further their emotional intelligence skill. Hence, it positively impacts students' academics and teachers' performance as well by the way it is a major responsibility of developing emotional intelligence competency for lecturers of their higher authorities. This study may help to integrate investigations of emotional intelligence in the field of psychology and expand these findings to the educational processes of lecturers in higher education. Enhancement of emotional intelligence is very much required not only in the field of school education but in all the areas of higher education also should be concerned about it. The results of this study will enable teachers in higher education to better align with the demanded skill called emotional intelligence for getting student engagement.

\section{Recommendation}

There should be a proper mechanism to get students' concerns in terms of feedbacks about lecturers' performance individually. When focusing the in-depth analysis on the students' point of view and ensure the needful readjustments are taken place, which meets the students' requirement in the phase of effective learning and teaching, then obviously it will turn up students to be more engaged on academics.

Forming more flexible rapport with students will make talk free environment; thus, the knowledge sharing process can be effectively taken place, and students will be capable of questioning and clarifying their consents. Being sensitive towards students' perspectives, enthusiastic in hearing students matters whether it is academic-related or not, and develop them individually also make them engaged in learning more effectively. Conveyed the message through teaching should be ensured the worthiness of that. The interesting methods of teaching are taken place rather than ties on traditional methods. Alternatively, adopting new practices of technology advancement enrich to take interesting learning in which relevant authorities should fund the accommodations. But, it is not only on the hand of lecturers. Avoiding overlapping assignments and lacking in completion of the course contents even though the time pressure should be neglected.

\section{Conclusion, Limitations and Further Research}

Ultimately the findings reveal that students are engaged in academic activities. However, up to an extent, they are not committed to participate actively, so students are still having a certain problem to engage their academic activities fully. As per the undergraduates' perspective, lecturers are just good on emotional intelligence 
competencies rather than excellent enough; however, $49 \%$ of student engagement is explained by the emotional intelligence competencies of lecturers. There is a significant impact on teachers who interested to take students' consent and try to understand their perspectives. The teachers are personally available to serve (Social awareness competencies) and capable of persuading students' expectations, being a role model, developing graduates to cope with uncertainties, and an excellent communicator. Eradicate clashes with students and finally build an affective bond between lecturers and undergraduates (Relationship management) on student engagement.

The study revealed great attention has to pay towards the skills of teaching, which is beyond the technical skills, too (the subject knowledge) simply. This means what the students are expecting, called emotional intelligence competencies. University is the place where students are granted the opportunity to become wise. So effective teaching methods is one of a significant factor in the higher education system. If teachers are supposed to take a student-centered teaching approach, which can simplify as learners and learning approach, that's what it demands teachers in higher education. Student-centered teaching should be a great effort devoted to developing social competencies on emotional intelligence. Thus emotionally intelligent teachers can perceive and mold their own emotions by understanding students' emotions and managing relationships with them. Finally, tremendously, it will help to ensure active student engagement in academic activities.

There are two ideologies stand to define what is emotional intelligence is, first, understand one's self and secondly, others, and their feeling. (Goleman, 2006). The current study was attempted to analyze teachers' emotional intelligence competencies based on the students' perspective. Thus, one limitation of this study is only focused on the other ideology that understanding students feeling, wants, and interests to describe teachers' emotional intelligence. Therefore, it is recommended to conduct similar research by considering both ideologies to analyze teachers' emotional intelligence competencies. Finally, this is a cross-sectional study; sometimes, the findings may not be valid as time differences can happen; thus, for future researches, a longitudinal study is recommended.

\section{References}

Adi, S., \& Meirav, H. (2014). Teaching the teachers: emotional intelligence training for teachers. Teaching Education, 25, 375-390. https://doi.org/10.1080/10476210.2014.908838

Ahmed, H. (2015). Emotional Intelligence and Job Satisfaction among University Teachers. https://doi.org/10.2139/ssrn.2589038

Alferaih, A. (2017). A conceptual model for measuring Saudi banking managers' job performance based on their emotional intelligence (EI). International Journal of Organizational Analysis, 25(1), 123-145. https://doi.org/10.1108/IJOA-10-2014-0807

Astin, A. W., \& Sax, L. J. (1998). How are undergraduates affected by service participation? Journal of College Student Development, 39(3), 251-263.

Bashir, S., Bajwa, M., \& Rana, S. (2014). Teachers as role models and their impact on the life of female students. Internation Journal of Research Granthaalayah, 1(1).

Brackett, M. A., \& Katulak, N. A. (2006). Emotional Intelligence in the classroom; Skill-based training for teachers and students. Applying Emotional Intelligence. Psychology Press, UK.

Carol, R. (2012). Student engagement: What does this mean in practice in the context of higher education institutions? Journal of Applied Research in Higher Education, 4(2), 94-108. https://doi.org/10.1108/17581181211273039

Chechi, K. V. (2012). Emotional intelligence and teaching. International Journal of Research in Economics \& Social Sciences, 2, 297-304.

Cohen, J. (2006). Social, emotional, ethical and academic education: Creating a climate for learning, participation in democracy and well-being. Harvard Educational Review, 76(2), 201-237. https://doi.org/10.17763/haer.76.2.j44854x1524644vn

Constanti, P., \& Gibbs, P. (2004). Higher education teachers and emotional labor. International Journal of Educational Management, 18(4), 243-249. https://doi.org/10.1108/09513540410538822

Cooper, B. (2004). Empathy, interaction and caring: Teachers' roles in a constrained environment. Pastoral Care in Education, 4, 12-21. https://doi.org/10.1111/j.0264-3944.2004.00299.x

Deniz, S. (2010). Implications of training student teachers of pre-schooling through micro-teaching activities for a classroom with mentally-disabled students. Educational Research and Reviews, 5(6), 338-346. 
Edannur, S. (2010). Emotional intelligence of teacher educators. International Journal of education science, 2, 115-121. https://doi.org/10.1080/09751122.2010.11889988

Emma, C. M., \& Lorna, C. (2017). Measuring student engagement in UK higher education: do surveys deliver? Applied Research in Higher Education, 9(2), 226-241. https://doi.org/10.1108/JARHE-11-2015-0082

FME, T. (2017). Retrieved from http://www.free-management-ebooks.com

Embry, D. D. (2002). The Good Behavior Game: A Best Practice Candidate as a Universal Behavioral Vaccine. Clinical Child and Family Psychology Review, 5(4), 273-297. https://doi.org/10.1023/A:1020977107086

Ergur, D. O. (2009). How can education professionals become emotionally intelligent? World Conference on Educational Sciences. Procedia Social and Behavioral Sciences, 1, 1023-1028. https://doi.org/10.1016/j.sbspro.2009.01.183

Giardini, A., \& Frese, M. (2006). Reducing the negative effects of emotion work in service occupations: emotional competence as a psychological resource. Journal of Occupational Health Psychology, 11(01), 63-75. https://doi.org/10.1037/1076-8998.11.1.63

Goleman, D. (2006). Emotional Intelligence, Why it can matter more than IQ. Bantam 10th anniversary reissue edition.

Goleman, D. (1998). Working with Emotional Intelligence. Bantam Books. 0553104624, 9780553104622. https://doi.org/10.1002/lt1.40619981008

Goleman, D. (2001). Emotional intelligence: perspectives on a theory of performance. In C. Cherniss \& D. Goleman (Eds.), The emotionally intelligent workplace. San Francisco: Jossey-Bass.

Good, T. L., \& Brophy, J. E. (2006). Looking in classrooms (8th ed.). New York: Longman.

Greenberg, M. T., Weissberg, R. P., o' Brien, M. U., Elias, M. J. Resinik, H., Zins, J. E., \& Fredericks. (2003). Enhancing School-Based Prevention and Youth Development Through Coordinated Social, Emotional, and Academic Learning. American Psychologist, 58(6-7), 466-474. https://doi.org/10.1037/0003-066X.58.6-7.466

Hamdan, J. A. (2007). Higher Education Classroom Management: Kuwait University Students' Views. College Student Journal, 14(3).

Hammond. (1999). Teacher Quality and Student Achievement: A Review of State Policy Evidence. Education Policy Analysis Archives, 8(1), 1-44. https://doi.org/10.14507/epaa.v8n1.2000

Hu, R. J. S. (2011). The relationship between demotivation and EFL learners' English language proficiency. English Language Teaching, 4(4), 88. https://doi.org/10.5539/elt.v4n4p88

Hadi, H., \& Mohammad, K. (2016). The Interplay among Emotional Intelligence, Classroom Management, and Language Proficiency of Iranian EFL Teachers.

Hargreaves, A. (1998). The emotional practice of teaching. Teaching and Teacher Education, 14, 835-854. https://doi.org/10.1016/S0742-051X(98)00025-0

Hargreaves, A. (1998b). The emotional politics of teaching and teacher development: with implications for educational leadership. International Journal of Leadership in Education, 1, 315-336. https://doi.org/10.1080/1360312980010401

Hong-Biao, Y., John, C. K. L., Zhang, Z. H., \& Yu-le, J. (2013). Exploring the relationship between teachers' emotional intelligence, emotional labor strategies, and teaching satisfaction. Teaching and Teacher Education, 137-145. https://doi.org/10.1016/j.tate.2013.06.006

Jennifer, A. F., Phyllis, C. B., \& Alison, H. P. (2004). School Engagement: Potential of the Concept, State of the Evidence. https://doi.org/10.3102/00346543074001059

Jennings, P. A., \& Greenberg, M. T. (2009). The outcomes Prosocial Classroom: Teacher Social and Emotional Competence in Relation to Student and Classroom Outcomes, Review of Educational Research, 79, 491. https://doi.org/10.3102/0034654308325693

Kahu, E. R. (2013). Framing student engagement in higher education. Studies in Higher Education, 38(5), 758-773. https://doi.org/10.1080/03075079.2011.598505

Kovaceic, P. M. (2012). Adaptation and validation of the teacher emotional labor strategy scale in China. 
Experimental Educational Psychology, 32, 451-465. https://doi.org/10.1080/01443410.2012.674488

Kremenitze, A. J. P., \& Miller, R. (2005). Are You a Highly Qualified, Emotionally Intelligent Early Childhood Educator? Teachers' Early Childhood Professionals. National Association for the Education of Young Children. Retrieved from www.naeyc.org

Kuh, G. D. (2005). The National Survey of Student Engagement: Conceptual and Empirical Foundations. New Directions for Institutional research.

Kyle, W., Brett, C., Lathan, N., \& Palmer, F. (2016). A positive approach to management education: The relationship between academic PsyCap and student engagement. Journal of Management Development.

Lowman., J. (1984). Mastering the Techniques of Teaching. San Francisco: Jossey-Bass.

Madeline, J., \& Sue, E. (2007). Emotional Intelligence and Begining Teacher Candidates. Education, 127(4), 456-461.

Mayer, J. D., \& Salovey, P. (1990). Emotional Intelligence. Imagination, Cognition, and Personality, 9(3), 185-211. https://doi.org/10.2190/DUGG-P24E-52WK-6CDG

Markwell, D. (2007). The Challenge of Student Engagement. Keynote address at the Teaching and Learning Forum. University of Western Australia, 30-31 January.

Mendes, E. (2003). Building classroom relationship: What empathy can do? Education Leadership, 61, 56-59.

Mottet, P., \& Beebe, S. A. (2006). The Relationships Between Student Responsive Behaviors, Student Socio-Communicative Style, and Instructors' Subjective and Objective Assessments of Student Work, Communication Education, 55(3), 295-312. https://doi.org/10.1080/03634520600748581

N.Ramanathan, H. (2015). Effect of Emotional Intelligence, Caring Orientations and Emotional Labor Strategies on Job Involvement of Teachers in Higher education. Kelaniya Journal of Human Resource, 141-158.

Nahid, N. A. (2012). Teachers: emotional intelligence, job satisfaction, and organizational commitment. Workplace Learning, 24(4), 256-269. https://doi.org/10.1108/13665621211223379

Nassudin, O. E. (2012). Factors influencing students' academic aspirations higher. 6th International Conference on University Learning and Teaching (InCULT 2012). Elsevier Ltd.

Nicolini, P. (2010). Training teachers to observation: An approach through multiple intelligences theory. Bulletin of the Transilvania University of Braşov, 3(52), 91-98.

Nina, B. (2015). Teachers' emotional intelligence - A vital component in the learning process. Book Chapter, Universityteti-Lodzkiego. Retrieved from https:// hdl.handle.net/11089/14974

Ogbonna, E., \& Harris, L. C. (2004). Work Intensification and Emotional Labour among UK University Lecturers: An Exploratory Study. Organizational Studies. 25(7), 1185-1203. https://doi.org/10.1177\%2F0170840604046315

Oplatka, I. (2007). The place of the open house in the school choice process: Insights from Canadian parents' children and teachers. Urban Education, 42(02), 163-184. https://doi.org/10.1177/0042085906296561

Pekrun, R., Goetz, T., Titz, W., \& Perry, R. P. (2002). Academic emotions in students' self-regulated learning and achievement: A program of qualitative and quantitative research. Educational Psychologist, 37, 91-105. https://doi.org/10.1207/S15326985EP3702_4

Petrides, K. V., Pita, R., \& Kokkinaki, F. (2007). The Location of Trait Emotional Intelligence in Personality Factor Space. British Journal of Psychology, 98, 273-289. https://doi.org/10.1348/000712606X120618

Petrides, K. V., \& Furnham, A. (2003). Trait Emotional Intelligence: Behavioural Validation in Two Studies of Emotion Recognition and Reactivity to Mood Induction. European Journal of personality, 17(1), 39-57. https://doi.org/10.1002/per.466

Phommasa, P. (2016). How Southeast Asian American Students Persist in the University Permalink. Peer-reviewed Thesis. Retrieved from https://escholarship.org/uc/item/4fj263sp

Zhang, Q., \& Zhu, W. H. (2008). Exploring Emotion in Teaching: Emotional Labor, Burnout, and Satisfaction in Chinese Higher Education. Communication Education. https://doi.org/10.1080/03634520701586310

Richardson, B. G., \& Shupe, M. (2003). The Importance of Teacher Self-Awareness in Working with Students with Emotional and Behavioral Disorders. Teachning Expectional Children. 
https://doi.org/10.1177/004005990303600201

Ritter, J. T., \& Hancock, D. R. (2007). Exploring the relationship between certification sources, experience levels, and classroom management orientations of classroom teachers. Teaching and Teacher Education, 23(7), 1206-1216. https://doi.org/10.1016/j.tate.2006.04.013

Rust, D. A. (2014). Relationship between the Emotional Intelligence of Teachers and Student Academic Achievement. Educational Leadership studies. Theses and Dissertations--Educational Leadership Studies, 8. Retrieved from https://uknowledge.uky.edu/edl_etds/8

Sekaran, U. (2006). Research methods for business: A skill-building approach. John Wiley \& Sons.

Singh, J. D. (2015). A Study of Emotional Intelligence of Teachers Educators in Relation to Demographical Variables. pp.2883-2893.

Tettegah, S., \& Anderson, C. J. (2007). Pre-service teachers' empathy and cognitions: Statis-tical analysis of text data by graphical models. Contemporary Educational Psychology, 32, 48-82. https://doi.org/10.1016/j.cedpsych.2006.10.010

Trowler, V. (2010). Student engagement literature review. Department of Educational Research at Lancaster University.

Trigwell, K. (2012). Relations between teachers' emotions in teaching and their approaches to teaching in higher education. Instructional Science, 40(3), 607- 621. https://doi.org/10.1007/s11251-011-9192-3

Winograd, K. (2005). The Functions of Teacher Emotions: The Good, the Bad, and the Ugly. Teachers College Record, 105(9), 1641-1673. https://doi.org/10.1046/j.1467-9620.2003.00304.x

Yin, H. (2015). The effect of teachers' emotional labor on teaching satisfaction moderation of emotional. Teachers and Teaching, 21(7), 789-810. https://doi.org/10.1080/13540602.2014.995482

Zhang, Q., \& Zhu, W. (2008). Exploring Emotion in Teaching: Emotional Labor, Burnout, and Satisfaction in Chinese Higher Education. Communication Education, 57(1), 105-112.

https://doi.org/10.1080/03634520701586310

\section{Copyrights}

Copyright for this article is retained by the author(s), with first publication rights granted to the journal.

This is an open-access article distributed under the terms and conditions of the Creative Commons Attribution license (http://creativecommons.org/licenses/by/4.0/). 